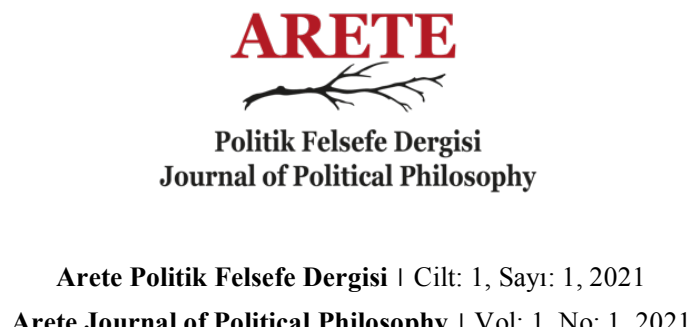

Arete Journal of Political Philosophy I Vol: 1, No: 1, 2021

Gönderim Tarihi I Received: 02.03.2021

Kabul Tarihi I Accepted: 19.03.2021

www.aretejournal.org

Çeviri | Translation

\title{
Jean-Luc Nancy: "Düşünme Konusundaki Kötü Alışkanlıklarımız Şu Anın Havasını Gölgeliyor!’” *
}

(Fransızcadan Türkçeye Çeviren: Zeliha Diş̧Ci) ${ }^{* *}$

Filozof Jean-Luc Nancy, son makalesinde bizi şu ana kendimizi adamaya davet ediyor ve görünüşte bizi birbirimizden uzak tutan virüsün topluluğu bir araya getirdiğinin altını çiziyor. Sansürcülük karşısında konuşmaya ayrıcalık tanıyan ve eleştiriyi sağduyuya tercih eden büyük düşünürlerimizden biri ile röportajımız.

Marianne (M): Kuşağınızın en önemli düşünürlerinden birisiniz. Size ‘filozof’ mu yoksa 'düşünür' mü demeliyiz?

Jean-Luc Nancy (JLN): 'Filozof' derken dünyanın -ilkelerinin ve amaçlarınıntemsili anlamındaki bir 'felsefe'yi inceden inceye işleyen biri anlaşıllyorsa, o halde

\footnotetext{
* Söyleşinin Fransızca aslını şu internet adresinde bulabilirsiniz (For the French version): https://www.marianne.net/culture/litterature/jean-luc-nancy-nos-mauvaises-habitudes-de-penser-brouillent-lasaveur-du-present

** Dr. Öğr. Üyesi I Assist. Prof.

Siyaset Bilimi ve Kamu Yönetimi Bölümü, Kafkas Üniversitesi|Political Science and Public Administration Department, Kafkas University.

zelihadisci@gmail.com

Orcid Id: 0000-0001-5650-680X

Doi: http://dx.doi.org/10.47614/arete.29

Nancy, J.L. (2021). Düşünme Konusundaki Kötü Alışkanlıklarımız Şu Anın Havasını Gölgeliyor (Marienne ile Söyleşi). (Zeliha Dişci Çev.). Arete Politik Felsefe Dergisi. 1(1). 155-162.
} 
düşüncenin bir temsilde sona erememesi bakımından düşünür filozoftan ayrılır. Düşünür, temsilleri onlarda ele geçirilemeyen şeye doğru tekrar tekrar aşar. Tarihin tanınmış filozoflarında iki açı da mevcuttur: Hemen hepsi, hatta Hegel bile! hem temsile hem de onun ötesine doğru temayül içindedir.

M: Yirminci ve yirmi birinci yüzyıl düşünce alanı içinde çalışmalarınızı nereye konumlandirırsinız?

JLN: 1940'ta doğdum, 1950'lerin ve 1960'ların, yani savaş sonrasında beliren, fakat Nietzsche, Freud, Heidegger tarafından çoktan ifade edilmiş olan düşünceler bütününün çocuğuyum: Tüm anlam yapılarını ve bütün "mevcudiyet” temsillerini - yani şeylerin mevcudiyetini ya da kendinde-mevcudiyeti - yeniden oyuna sokma ihtiyacına dair düşünceler bütününün. -Çok genç yaşlarımın Sartre'ından sonra,- 'tarih'in (Foucault, Levi-Strauss) yanı sira 'varlık'ın (Heidegger) ve 'özne'nin (Heidegger, Freud) istikrarsızlaşmasından doğan her şeyi yeni bir başlangıç olarak karşıladım. Geri planda benim için temel bir motif vardı: yorumlama, düşüncenin çoğalması. Bütün bunlar beni belirli bir zamana konumlandırmaz: Aksine, ben çağım tarafından şekillendirildim ya da sürüklendim.

M: Felsefe için, fillozofların sesinin ve sözlerinin siyasal tartışmalarda bile yankılandığg ihtişamlı günler bitmiş ya da en azından seyrelmiş görünüyor. $\mathrm{Bu}$, toplumdan üniversiteye seçilmiş bir geri çekilme, katlanılan bir düşüş, (göreceli) bir sürgün mü?

JLN: Ne bir tehdit ne de geri çekilme sorunu bu. Basitçe söylemek gerekirse, felsefe sadece kendisine düşünmek için verileni düşünür. "Biz" - eğer bu topluluğa firsat verirsem- tarih, politika, hukuk, öznellik, kimlik vb. düşüncenin tüm dönüşümleri hakkında çalıştık - ve yeni düşünceleri yaratmadığı açığa çıktı. Aksine, tüm kabartmalarda genel bir gerileme yaşandı: Tekno finans efendileri ve olduğumuz gezgin zombiler arasındaki uçurumun artmasına rağmen bugün Birleşik Devletler'deki özne ve nesne, ölü ve canlı, zengin ve yoksul her şeyi aynı düzleme koymak üzere "düzlemler ontolojisi”nin keşfedilmesini bir düşünün. Bunun da elbette ki öngörülemez sonuçları olacak! Biz de bu öngörülemezden öncesini düşünmeliyiz. 
M: Yirminci yüzyılın en etkili isimleri arasındaki Marx ve Heidegger, bugün tüm kötülükler yüzünden suçlanıyorlar. Sartre, aynı toptancı ve tasfiyeci hareketin kurbanı. Freud, Lacan... psikanaliz artık sezonunda değil. Bir entelektüel tasfiye dürtüsü, geçmiş eserlerle diyalog eksikliği mi var?

JLN: Karmakarışık eden veya mahrum etmek isteyen eder! Benim için, Marx, Heidegger, Freud ve bana onlardan Derrida, Deleuze, Lacan adındaki bu önemli aktarımlar her zaman aynı derecede günceldir. Kant'tan, Hegel' den, Nietzsche'den daima toplanmaya hazır yeni şeylerden söz etmeye gerek bile yok...

M: Heidegger'e, Chaiers Noirs'ın (Gallimard) yayınlanmasını takiben, yöneltilen suçlamalar hakkında ne düşünüyorsunuz? Bu kış yayınlanan Méditation'un (Gallimard) bazı bölümleri açık bir şekilde Nazizim ve Hitler ile arasına mesafe koyuyor.

JLN: Heidegger, meydan okuduğu metafizik sahneyi tekrar oynayan bir "Varlık fikrini” oyunun başında veyahut neredeyse başında tasavvur ederek büyük bir hata yaptı. Ve bu onu bir tür entelektüel histeriye sürükledi. Halbuki baştan beri, aynı madalyonun önü veya ters yüzü olduğundan dolayı, "varlık hiçliktir” düşüncesini, yani ne diyalektik ne de nihilist bir olumsuzluğun olanağını dile getirmişti. 1933’ten sonra Hitler ve diğerlerinin yanı sıra bütün toplumumuz hakkında bu kadar net olmasının sebebi budur. "Méditation" da bahsettikleriniz elbette var ama Cahier Noir da bunlarla dolu!

Bunu anlamak çok önemli, esasında kanımca Derrida bunu çok iyi anlamıştı. Çünkü Heidegger ile bütün yaşamını ayrıntısıyla ele aldı. De L'Esprit'i yeniden okuyun: İşte size Heidegger'i kendi dışına taşıyan bir kitap! Dolayısıyla Heidegger'in kendisi hakkında çok fazla tartışmak gereksiz. Levinas, Ganel, Derrida ve birkaç başka düşünür bunun çok ötesine geçti. Ötesindeyiz -ki bu da tabii olarak oradan geldiğimiz anlamına gelir, fakat önümüzde Heidegger'in geldiğini göremediği başka çalışma alanları da var.

M: Birkaç ay önce, medyatik bir yazar Millî Eğitim Bakanlığı'ndan Heidegger' in lise sonda çalışılabilecek yazarlar listesinden çıkarılmasını talep etti. Vincent Cespedes'in bu girişimi sizde nasıl bir fikre kapı aralıyor?

JLN: Vah vah, ne yazık! Metinleri-Heidegger'in ve hatta az önce zikrettiğim kişilerin metinlerini-okumak yerine onlar üzerine alelacele yazılmış değerlendirmeleri döne döne düşünmeyi ne zaman bırakacağız. Bütün bunlar uyurgezerce bir özgüvenden 
ileri geliyor: Bildiğimizi zannederiz ve her şeyden evvel iyi bir günah keçimiz, gerçek bir piçimiz vardır. Bu yeterli. Tüm toplumumuzun kendisi yoluyla dünyanın kapitol-teknik yönetim planını takip ettiği temiz vicdanda pisliğin de bulunabilmesi haricinde... Bugüne kadar bu pislik oraya sıkışıp kalmış bulunuyor.

Derslerinizden hatırladığınız şeyi çok iyi anlıyorum ve ekleyebilirim de: Cahier Noir'i gözden geçirin ve örneğin 'sayılamayan' meselesi hakkındaki bir dizi notu bir araya getirin ve burada kültürümüzün, politikamızın, ahlakımızın içine sıkıştığı hiperhesaplanabilirlik hakkında öğrencilerin çalışacağı ne kadar çok şey olduğuna bakın. Elbette Seyn'deki [Varlık'taki] büyülü sözcükleri çıkarmak gerekirdi! Fakat Heidegger'in artık varlığı özdeşleştirmemek ve yalnızca fiili düşünmek gerektiğini... ve bu fiili geçişli hale getirmek gerektiği düşüncesini olumladığı birkaç metne geri dönerseniz... O zaman temelde kendisiyle çeliştiğini anlarsınız! Ama okumak gerekir, hay Allah!

M: Profesör René Chiche başta olmak üzere kimileri tarafından, La Désinstruction Nationale (Ovadia) adlı kitabıyla Jean-Michel Blanquer Fransız okul sisteminin özgünlügünü oluşturan ortaöğretimde felsefenin izini silmekle eleştirildi. Felsefenin Fransa'daki durumu hakkında ne söylersiniz?

JLN: Bahsettiğiniz kitabı bilmiyorum. Öte yandan, lisede felsefe eğitiminin güncel koşulları hakkında bilgim var. Aralarında oldukça genç olanların da bulunduğu öğretmenler tanıyorum. Birçoğu için felsefe programları tarafından yapılan tanımın alımlanmasının, dil bilgisinden (ve bazen örneğin Rousseau'daki gibi, dilin eski hallerinden) dikkat kapasitesine, yazma becerisine kadar giden kümülatif nedenlerden dolayı çok sıklıkla zor olduğunu biliyorum. Tanım, doğrudan kavranabilen pratik karakteri olmayan bir şeydir ve bu yüzden sıklıkla ilgisizlikle karşılanır. Bir sınıfta her zaman tefekkür için "can atan” birkaç öğrenci olur, fakat bu büyük çoğunluğa sıkıcı ve hatta itici gelir. Felsefe, mavi kot-pantolon ve spor ayakkabılı bir bedenin üstündeki peruklu bir kafa olarak sona yaklaşıyor. Geçen yıllar elli yıl önceki birinci sınıf öğrencisindeki dil, analiz, tartışma etkisini yaratmadı.

$\mathrm{Bu}$ nedenle, felsefeye lise son sınıftan önce başlama isteğini anlıyorum, fakat... Bunun Felsefe Eğitimi Araştırma Grubu (Derrida, Chatelet, Sarah Kofman ve diğerleri) tarafından önerilmesinden buyana neredeyse elli yıl geçti. O zamanlar bir edebiyat 
meslektaşımla beşinci sınıfta iki yıllık deneyimim vardı. Heyecan vericiydi ama devam etmeye gücümüz yetmedi. Bunun hakkında düşünmekten vazgeçmedim: Tüm programları, kavramları, yazarları ve uygulamaları bir kenara bırakarak, yeniden düşüncede nasıl bir başlangıç modeli oluşturabiliriz? Bana kalırsa özel bir disiplin keşfetmek gerekirdi. Bu disipline "tartışma" veya "çekişme" ya da basitçe "diskur" (veyahut "diskur sanatları ve bilimi”) denebilirdi ve "diskur" kelimesinin taşıdığı tüm anlamları derinlemesine araştırmayla başlanabilirdi. Üçüncü veya ikinci sınıftan itibaren felsefe hakkında konuşulurdu fakat öncelikle konuşma/tartışma/gösterme/kanıtlama/ikna etme/inandırma/fikir verme... vb. hakkında konuşulurdu. Tüm bunlar açık bir şekilde tüm disiplinlerle bağlantılıdır ve her yöne hareket edip çalışmayı mümkün kılar. Ve bu tam olarak çoğu insanın iktidar, bilinç veya güzellik hakkındaki akademik diskurları öğrenince elde ettikleri bir şeydir.

Meslektaşımız Chiche'nin birkaç ifadesine bakıyorum: Görüşünü paylaşabilirim. Tabii ki okulun mevcut durumunun nereden geldiğini göz ardı eden bir ithamla kendimi tekrar karşı karşıya buluyorum. Pedagojide veya sosyolojide bir itaat, gevşeklik veya bilinçsizlik suçlaması, vs. var. Fakat bir toplumun ve kültürün tamamı uzun zamandan beri işleyiş biçimini benimsemiş durumda. Niçin? Çünkü kendi kendimize öğretebildiklerimizde ve öğretmek zorunda olduklarımızda giderek kontrolümüzü yitiriyoruz. Hangi dil konuşulacak? 1950'li yıllardan itibaren bu soru Fransız profesörler tarafından soruldu. Hangi matematik ve fizik öğretilecek? 1960'lardan beridir soruluyor. Her iki durumda da yanıtlar bariz sebeplerle tersine çevrildi. Ya tarih ile coğrafya? Her şey değişirken ve aynı zamanda analiz sistemlerini de önemli ölçüde değiştirirken onlar neye dönüşür? Napolyon dönemi lisesi için tasarlanan, sonrasında Cumhuriyet döneminde yeniden pudralanan zavallı felsefe bu yüzden yılların ağır yükü altında ezilmeye başladi.

1964 'te lisede öğretmenliğe başladım. Platon'un Phaidon'unu okuyacağımızı ve kitabın ruh meselesiyle ilgili olduğunu duyurdum. Bir öğrenci şöyle çıkıştı: “Bu eski püskü şeylerle ne yapılır ki?” Çok iyi bir öğrenciydi. Bu kendimi iyi hissettirdi, çünkü “ruh”un neyi kapsayabileceğini açıklamam gerekti. Fakat bu elli yıl kadar önceydi. Bugün sözüm dinlenmediğinden müdahale de olmazdı. Veya eğer söz dinlenmezse duyulamaz da. Duyurmak istediği şeyi bulmak topluma bağlıdır. 
M: Toplumda duyulan şey "Un Trop Humain Virus" (Bayard) isimli makalenizde takrarlanan "krizden düşünce yoluyla çıkış beklentisi"dir. Felsefeye bu başvuruyu, yardım talebinde bulunma olarak bu çağrıyı nasıl görüyorsunuz?

JLN: Doğrusunu söylemek gerekirse, felsefenin bilgelik ve umut verdiğine dair yaygın inanç uyarınca felsefeye yardım çağrısı var-veya vardı.-Bugün artık tarihe kenetlenmek üzere din (ki bu salgın karşısında hiç şüphesiz çok az yardımı olur) ve psikanaliz (hakikaten sosyal fenomenlere erişemez) dışında bir siyasal perspektif yok. Bu hem felsefeyi hem de durumumuzu -tinsel durumumuzu diyelim- daha iyi anlamak adına iyi bir fırsat. Felsefenin bir yaşam formu kapanırken geldiğini ilk defa Hegel söylemişti. Kendisi bu form ve formun kapanışı hakkında düşünme girişiminde bulunur bulunmasına, lakin -filozofların büyük oranda değerlendirmelerinden kaçıp kurtulan pratik, sosyal, ekonomik stratejilerden bahsetmedikçe- gelecek öngörülemez kalır.

M: Bu deneyimle Batı'nın ve özellikle de Avrupa'nın yüz yüze geldiği şey yanılmazlığııın sınanmasıdır. Son zamanlarda Batı'nın “her şeye kadir” gücünün zayıflamasının nedenleri teknik olduğu kadar kültürel de değil mi?

JLN: Dünyamızın ruhtan yoksun olduğunu söyleyen Marx’a göre, zayıflamanın nedenleri tinseldir. Rasyonalizmin ve hümanizmin-büyüklük ve güç sahibi olduklarızamanları oldu. Geçmişte kutsalın kendininkini tüketmiş olmasındaki gibi hem Akıl hem de İnsan, kaynaklarını tüketmişe benziyor.

M: Virüs "salona girdiğinden" beri, endişe yaygın, "programlamamızın dışına itiliyoruz." "Tüm felsefeyi doğuran" ölümün zamansızlığı korkusuna, bir yenisini, belirsizlik korkusunu ekler miydiniz?

JLN: Ölüm korkusu, kültürleri kuran şeye bağlı olarak değişir. Şimdiye kadar hiçbir kültür ölümü önemsiz ve tamamıyla steril hale getirmemişti. Herkes ölümü (hayatın içine) yedirmeyi biliyordu: Bizimkiler ise yaşamı üretime/tüketime indirgediklerinden bunu artık bilmiyorlar.

M: "Aslında virüs bizi müşterek kılıyor" diye durumu değerlendiriyorsunuz. Her bir kişinin kapanmaya özgü göreceli izolasyonu topluluğa nasıl bir katkı yapar? Haykırışa varıncaya değin her ses tonunda "yalnız hayvanlar" olmadığımız yeniden olumlanıyor. 
JLN: Çift yönlü bir hareket var. Bir yandan, herkes için durumun kırılgan oluşunu ve ortak sorumlulukları yerine getirmenin gerekliliğini keşfetmekteyiz. Diğer yandan, birdenbire bireysel veyahut sınıfsal "panik-olma"nın piyasaya çıktığını görüyoruz. $\mathrm{Bu}$ ikirciklilik, normal zamanlarda kendi yurttaşlarının çoğundan uzak mesafede yaşayan halk parçasının "sosyal mesafe" zorunluluğuna karşı itirazlarına iyi yansıyor. Dünyaya inen bir uzaylı şimdiye kadar bu toplumun her firsatta birbirine dokunduğunu, kucaklaştığını, öpüştüğünü düşünürdü. Aynısı özgürlükler için de geçerli: Sıradan yaşamımız, önemsiz görünen yürüyüş ve aperatif zamanı kısıtlaması kadar ekonomik, sosyal, kültürel sınırlamalara tabiydi. Burada söylediklerim elbette orta sınıflar için geçerli, onları kastediyorum. Zenginler bütün bunları umursamıyor ve fakirler de yoksulluklarının hâlen daha çok acısını çekiyor.

M: Bir sağlık tehdidi olarak virüs "varlıkları eşitler" ama maddi olarak toplumsal eşitsizlikleri harekete geçirir ve yeniden üretir. Pandemi ne şekildeki bir "küreselleşmenin ürünü’?

JLN: İnanıyorum ki, ekosistemdeki ayaklanmalar insanları hayvan patolojilerine maruz bırakırken, üretim ve mübadele koşulları paranın dolaşımıyla birlikte virüslerin dolaşımını desteklerken, teknik ilerlemeler daha iyi durumda olanların sağlık talebini çoğaltıp sefil, aç ve kötü muamele görenlerin kaderini değiştirmek için hiçbir şey yapmazken küreselleşmenin niteliği kanıtlandı ve kanıtlanmaya devam ediyor. Ve biz bu sürecin sonuna gelmiş değiliz, daha ne kadar kötüye gidebileceğini henüz görmedik.

M: "Nefes almayı ve yaşamayı yeniden öğrenmek zorundayız" diyorsunuz. Çağrınızı nasıl yanıtlamalı: "hadi çocuk olalım” gibi mi?

JLN: Bu, yeni baştan “tinsel” kelimesini kullanmak üzere, "tinsel” bir davet. Ancak tin, kelimenin ne askeri ne de ticari anlamıyla sorumludur. Tini işler kılmak ona sadık olmayı vaaz ederek olmaz, daha ziyade tam tersidir: Aniden yeni bir enerji ortaya çıtı̆̆ında belirli bir işe yönelik eğilimlere yol açar... Fakat elektrik ve algoritmaların dışında belki de artık enerji yoktur. Şunu söylemek kötümser olmak anlamına gelmez: Gelmekte olan bir kere daha yine gelebilir, bilinmeyenin derinliklerinden su yüzüne çıkabilir. Bu ısrarla dünyanın, virüslü veya virüssüz, yaşanamaz olduğunu ve ondan yararlananların ve mustarip olanların var olduğunu söylemeye engel teşkil etmez. 
M: Gelmekte olandan bahsetmişken, La Peau Fragile Du Monde' da (Galilee) onu geçmiş ve gelecekten bağımsız bir şekilde kavrıyorsunuz. Halen şimdiyi geliştirme ve böyle bir bağlamda ona inanma, (Aragon) şiiriyle söylersek, "yağmur düştüğünde güneşe inanma" olanağ 1 var mı?

JLN: Şu an, gelen ve gidendir. Bütün hayatımız bundan ibaret: durmadan gelir ve gider. Geçmiş hatırlanabilir, bu veya şu şekilde bir gelecek hayal edilebilir, fakat anılar ve beklentiler bizatihi şimdinin bir parçasından, onun dengesiz, geçici kırılganlığından oluşur. Aşk dolu veya estetik bir duygunun en güzel anı geçer. İsyan ateşinin veya sportif faaliyetin coşkusu parlar ve geçer. Buna aşinayız.

Lakin, bir yandan "ilerleme”, "büyüme”, "hızlanma”, diğer yandan "pişmanlıklar”, "kayıplar", "altın çağlar” ... vb. kanalıyla kötü düşünme alışkanlıklarımız şu anın tadını kaçırır. Bir karşılaşma, gülümseme, bir cümle, bir 1şık gibi çok basit sevinçlerde bile şimdiyi deneyimleriz. Şimdi aslında gelişip serpilir. Bir kültürün varlık sebebi de budur: Formlar, simgeler, tatlar veyahut tınılar-Rancière'in ifadesiyle "duyulurun paylaşımı." Ama sadece geçen zamanın ve gelecek zamanın hesabı tutulursa, yalnızca kazançlar veya kayıplar açısından şimdi hakkında düşünülürse, işte o zaman şimdi diye bir şeyden bahsedilemez. Elbette her anıyla endişe içermeyen bir yaşam koşullarına ihtiyaç var: $\mathrm{Ne}$ yiyeceğim? Nerede uyuyacağım? Ayın sonu nasıl gelecek? Ne zaman iyileşeceğim? Bir kültür veya bir uygarlık bu sıkıntıların olabildiğince azalmasını gerektirir. Şu anda her şey onları canlandırmak amacıyla yapılıyor gibi görünüyor. 